\title{
Meanings and dimensions of cancer by sick people - a structural analysis of social representations*
}

\author{
Sentidos e dimensões do câncer por pessoas adoecidas - \\ análise estrutural das representações sociais \\ Sentidos y dimensiones del cáncer por personas enfermas - \\ análisis estructural de las representaciones sociales
}

How to cite this article:

Wakiuchi J, Oliveira DC, Marcon SS, Oliveira MLF, Sales CA. Meanings and dimensions of cancer by sick people - a structural analysis of social representations. Rev Esc Enferm USP. 2020;54:e03504. DOI: http://dx.doi.org/10.1590/S1980-220X2018023203504

\section{Julia Wakiuchi ${ }^{1}$ \\ Denize Cristina de Oliveira ${ }^{2}$ \\ Sonia Silva Marcon ${ }^{3}$ \\ Magda Lúcia Felix de Oliveira ${ }^{3}$ \\ Catarina Aparecida Sales ${ }^{3}$}

* Extracted from the thesis: "Representações Sociais do câncer e da quimioterapia para pessoas adoecidas", Programa de Pós-

Graduação em Enfermagem, Universidade Estadual de Maringá, 2017.

${ }^{1}$ Centro Universitário de Brusque - Unifebe, Curso de Medicina, Brusque, SC, Brazil.

${ }^{2}$ Universidade do Estado do Rio de Janeiro, Programa de Pós-Graduação em Enfermagem, Rio de Janeiro, RJ, Brazil.

${ }^{3}$ Universidade Estadual de Maringá,

Programa de Pós-Graduação em

Enfermagem, Maringá, PR, Brazil

\section{ABSTRACT}

Objective: To describe the contents and structure of the social representation of cancer. Method: A qualitative study based on the Theory of Social Representations, carried out in a High Complexity Care Unit in Oncology. Data collection included a sociooccupational and clinical characterization questionnaire and free evocations form from 100 cancer patients in chemotherapy treatment and in-depth interviews with 29 of them. The analysis was performed using EVOC software. Results: One hundred (100) patients participated in the study. The social representation of cancer has the words normal, difficult disease, death and fear in its central nucleus. The apparent ambivalence between the continuity of life and its finitude as structuring meanings of this representation enables establishing an inferential hypothesis that relates normal disease to the possibility of treatment, control and cure of cancer, while the fear of death remains in the representational field linked to the disease, which has a difficult treatment to cope with. Conclusion: The social representations of cancer based on the presented interrelationships provide reflections which may contribute to increasing the individual and social care of patients with malignant neoplasm and their family in health services.

\section{DESCRIPTORS}

Neoplasms; Oncology Nursing; Psychology, Social. 


\section{INTRODUCTION}

Cancer is a chronic-degenerative disease characterized by disordered growth and rapid spread at the local or systemic level ${ }^{(1)}$. It is a socially feared pathology due to its clinical conditions and therapeutic complexity, also being related to the finitude in the everyday and professional imaginations since the first reports of its existence ${ }^{(2-3)}$. The difficulty of controlling cancer and its consequent potential for lethality have marked the history of the disease, associating it with a devastating evil, responsible for the instability of the body as a whole ${ }^{(4)}$.

In this sense, neoplasia is subject to stigmatization, associated with death, disfigurement, body deterioration, suffering and pain ${ }^{(2)}$. The very word cancer is related to the negative implications of the disease, and even its pronunciation is repressed by some patients in an attempt to deny it or to move away from the suffering it brings ${ }^{(5)}$.

For people who are ill, cancer can be a castigation, a punishment or something that comes to devastate their lives. These perceptions are mainly based on the changes that the disease and its treatments can cause, constructed from the experiences of people who have already faced their therapeutic path $^{(6)}$. Significant changes in the patients' lives take place after the diagnosis, so that questions about illness, life and death begin to take over their thoughts in an increasing way, becoming more significant as treatments are introduced ${ }^{(5)}$.

Studies that analyzed the social representations of cancer have shown predominantly negative dimensions for the patients, who mainly verbalize death, pain, suffering, disease and its severity, in addition to the chemotherapy treatment itself, relating them to the difficulties of coping with cancer ${ }^{(3,7)}$.

Despite the strong correlation of neoplasia with death and suffering, it is necessary to think of new ways of signifying the experience of the disease in contemporary times, which varies in its forms of 'living, feeling and speaking' according to the social actors involved, places occupied in space and transformations over time ${ }^{(2)}$. With regard to cancer, antineoplastic treatments have been extensively developed in recent years, which has had an impact on patients' survival $^{(8)}$, and possibly on perceptions and symbolic constructions of the disease. Given this context, the proposed question is: how are representations about cancer organized in the group of patients today?

In this sense, this study is justified due to the possibility of modifying the representations in face of changes in the social context and ideological environment related to the object. In addition, providing information and the consequent construction of social representations about cancer and its treatments may provide support for patients' participation in therapeutic decisions during the course of their illness ${ }^{(9)}$. The use of social representations in research enables unveiling the reality of social groups, encompassing the prescriptive elements of actions and behaviors of social groups in the environment that surrounds them.
Following these premises, the objective of this study is to describe the contents and structure of the social representations of cancer.

\section{METHOD}

\section{Study DESIGN}

This is an exploratory, descriptive, qualitative study based on the Theory of Social Representations (TSR), based on the assumptions of the Structural Approach or Central Nucleus Theory ${ }^{(10)}$. The TSR is defined as a specific knowledge form whose function is to recognize and elaborate behaviors between subjects through the interactions they present with the social environment, transforming it, meaning when individuals recognize themselves as part of a group that builds a reality ${ }^{(11)}$.

The TSR ${ }^{(11)}$ is considered a great theory, from which complementary approaches have emerged. Among these, the Central Nucleus Theory used in this study has the purpose of making TSR more heuristic for social practice and for research ${ }^{(12)}$. Through this approach, it is affirmed that the social representations are stabilized by a central nucleus $(\mathrm{CN})$, in which the shared meanings of the object under study are found. The peripheral elements which are closely related to the nucleus are organized around it, representing the various positions before the representation by the system of values and social norms that constitute the group's ideological environment and the relations that it maintains with the object ${ }^{(12)}$.

\section{SCENARIO}

The study was developed in a High Complexity Oncology Unit $(U N A C O N)$ located in the northern part of the state of Paraná with 100 cancer patients undergoing chemotherapy, and based on the following inclusion criteria: 18 years of age or older, being aware of their cancer diagnosis and having performed at least 3 months of chemotherapy treatment. Patients who had worsened clinical status were excluded, preventing them from expressing themselves verbally and those who died during the data collection period.

\section{DATA COLLECTION}

A questionnaire to characterize the participants, a form of free evocations and in-depth interviews were used to collect data. The subjects' characterization questionnaire was composed of questions that addressed sociodemographic, occupational and clinical characteristics of patients.

The free evocations form used to characterize the structure of social representation was applied to the participants by a single researcher, who asked them to express the first five words or expressions that occurred to them from the term "cancer", noting them in the order evoked. This technique is capable of accessing elements which could be masked in discursive production by its spontaneous character of expression, which enables reaching the semantic universe about the object under study in a faster and more accessible way ${ }^{(13)}$. It should be noted that all free evocation forms were completed 
by the researcher at the time of data collection, and did not provide participants with reflection moments on the evoked term, which would disregard the proposed method. The 100 study participants answered the characterization questionnaire and the free evocations form.

In-depth interviews were conducted with 29 patients who were selected for convenience among the 100 participants from the previous stages. The invitation was made to those who expressed the desire to report their perceptions and experiences about cancer in more detail. The institution provided an unoccupied doctor's office in the morning to ensure greater privacy during the interviews, which provided better freedom of expression to patients and comfort during the interviews. A semi-structured script was used in the interviews composed of three thematic blocks: 1 . Social representations about cancer and chemotherapy treatment; 2. Daily life of the patient undergoing chemotherapy; and 3. Care relationships established with the staff and the health service. The interviews had an average duration of 30 minutes.

\section{DATA ANALYSIS AND PROCESSING}

Descriptive statistics were used to analyze the sociodemographic and clinical data with the help of the Microsoft Excel 2010 program. In turn, the evocations were analyzed using EVOC 2005 software, which enabled organizing the representation content as well as its structure from constructing the Vergès matrix or prototypical analysis. The interviews aimed at revealing the semantic conjuncture of the evocations and confirming the inferences made from the analysis, making it possible to contextualize what is represented by the group in the patients' individual experiences. Thus, the interviews sought confirmation of the inferences proposed in the prototypical analysis, contextualizing them individually, in addition to validating the analysis of the relationship between the elements present in the representational structure.

\section{ETHICAL ASPECTS}

This study was developed under the ethical issues established by Resolution 466 of December 12,2012. The project was approved by the Standing Committee on Ethics in Research with human beings of the Universidade Estadual de Maringá, under opinion no. 1,328,979. Patient anonymity was preserved by using codes (e1, e2, e3 ... e100), followed by their age and diagnosis.

\section{RESULTS}

Among the 100 participants in the study, there was a predominance of females (67) and a higher concentration of the age group between 40 and 59 years of age (48). In relation to the residence, 90 lived with their family, and 74 were married or lived with a companion. Most of the subjects (50) had incomplete elementary school, while only two people had higher education.

The socio-occupational characterization of the patients after the illness reveals a total of 56 people removed from their occupation prior to diagnosis, 30 were retired, and only 10 continued to work during chemotherapy. It is noteworthy that 38 patients reported a decrease in individual income after starting treatment.

The main diagnoses observed among the patients were breast cancer (38), digestive organs (26) and male and female genital organs (16). Most of the interviewees (54) underwent adjuvant chemotherapy, i.e. in combination with radiotherapy or oncologic surgery.

The product of evocations from the term cancer inducer consisted of a total of 428 words, among which 116 were different. From this value, the minimum frequency of eight was established and the mean frequency (Average Order of Evocations) of 16 was calculated for constructing the Vergès matrix. The mean order of evocations was 2.70 on a scale of one to five.

Chart 1 presents the results of the performed analysis.

Chart 1 - Vergès matrix for the term inducer "Cancer" among patients with cancer in chemotherapy-Arapongas, PR, Brazil, 2017.

\begin{tabular}{|c|c|c|c|c|c|c|}
\hline & $<2.70$ & & & $\geq 2.70$ & & \\
\hline $\begin{array}{l}\text { Mean } \\
\text { Freq. }\end{array}$ & $\begin{array}{c}\text { Evoked } \\
\text { term }\end{array}$ & Freq. & $\begin{array}{l}\text { Average } \\
\text { Order of } \\
\text { Evocations }\end{array}$ & $\begin{array}{c}\text { Evoked } \\
\text { term }\end{array}$ & Freq. & $\begin{array}{c}\text { Average } \\
\text { Order of } \\
\text { Evocations }\end{array}$ \\
\hline$\geq 16$ & $\begin{array}{c}\text { normal } \\
\text { disease } \\
\text { difficult } \\
\text { death } \\
\text { fear }\end{array}$ & $\begin{array}{l}20 \\
17 \\
17 \\
16\end{array}$ & $\begin{array}{l}1.900 \\
2.000 \\
2.000 \\
1.875\end{array}$ & $\begin{array}{l}\text { God } \\
\text { treatment } \\
\text { cure }\end{array}$ & $\begin{array}{l}31 \\
30 \\
25\end{array}$ & $\begin{array}{l}3.161 \\
3.600 \\
3.360\end{array}$ \\
\hline$<16$ & $\begin{array}{c}\text { scary } \\
\text { denial } \\
\text { sadness }\end{array}$ & $\begin{array}{c}12 \\
10 \\
8\end{array}$ & $\begin{array}{l}2.500 \\
2.200 \\
1.500\end{array}$ & $\begin{array}{l}\text { family } \\
\text { fight } \\
\text { hope } \\
\text { pain }\end{array}$ & $\begin{array}{c}13 \\
13 \\
9 \\
8\end{array}$ & $\begin{array}{l}3.154 \\
3.308 \\
2.778 \\
3.625\end{array}$ \\
\hline
\end{tabular}

The prototypic analysis identifies the probable central nucleus $(\mathrm{CN})$ of social representation, located in the upper left quadrant of the table. The central elements have a high frequency and are more readily evoked, meaning that they are the most significant elements for the subjects under study. Thus, the terms normal disease, difficult, death and fear were evoked as a possible NC of the representation of cancer. Among these, difficult, death and fear elements express negative meanings, while the term normal illness symbolizes a positive or neutral element in this representational structure. It is possible to identify the presence of conceptual, imaginary and attitudinal dimensions from the contents of the $\mathrm{CN}$, which thereby compose a social representation.

A conceptual dimension is verified in the structure presented from the normal disease element through the word disease, associated with an attitudinal dimension of an evaluation character, present in the word normal. The difficult evocation also belongs to the attitudinal dimension that evidences the evaluation process of the subjects in relation to the illness process, and the word death is situated in an imaginary dimension, structuring the representational field of cancer rooted in the destruction of life. Finally, the $\mathrm{CN}$ has an affective dimension portrayed by fear, which is linked to death and the difficulties and uncertainties caused by the disease. 
We present excerpts from the interviews in order to contextualize the elements in the $\mathrm{CN}$ in which they were employed and their relationships. Linking cancer to a normal disease, the term most evoked by the participants, comes from the idea of a pathology which can be treated and cured today in an attempt to overcome its conception linked to death:

Now, I know it's a disease, but it's a treatable, curable disease. And it only is only cured if you receive treatment, because if the person goes there already discouraged, and they don't get treated, it isn't cured, and you will not see them return. So for me, cancer is a curable, treatable disease. I'm taking it good. It's being normal. I don't even think I have the disease. I think this way, sometimes it's like I have a flu, a more chronic illness, like high cholesterol, or diabetes. But I don't think of it like a tragic disease, I am leading my normal life (e20,34 years old, breast).

So cancer is a disease that, I know it's actually a disease that if you get diagnosed at the beginning it's easy to be cured, but it is a damn disease, it is. It has killed a lot of people (e53, 64 years old, prostate).

On the other hand, the word most readily evoked by the subjects in the CN (and in the whole table) was fear, with Average Order of Evocations of 1.875, related to the term death (Average Order of Evocations 2.000). Fear and death are present in the representations of cancer from the idea of death as a reality that permeates the disease prognosis, causing fear:

(...) today I'm still a little scared. I'm safe, because we found out early, but even so, deep down I have a little fear. I will not tell you that I don't, because I do. You know there are times that I'm thinking. There are times that I think like this: is it that my mind is acting within what I feel in my heart, that it will work, it will it be ok? But deep down, this fear... So I think I have this fear, we have a little fear, a fear. (e22, 52 years old, breast).

Everyone has a fear of dying, I will not say: - Oh, I don't care if I die. So ... But I'm trying to handle it the best way, and always asking God for strength (...). Only when I think about it I ask to die fast and I think I have this disease, then I get scared. I asked, now I have to deal with it. (e66, 53 years old, breast).

However, the difficult element expresses an evaluative dimension related to fear, to the search for to be cured, permeated by the treatment and all its mishaps, as can be observed in the speeches:

Difficult, very difficult. Terrifying ... but you have to try to get cured. I think of so many things ... it's a reality that you have to face, that you have to overcome. A difficult but necessary struggle ... that you have to reach the ultimate goal, which is the cure. At least try, with all your might (e4, 58 years old, breast).

(...) it's a difficult disease, there is treatment, the treatment is difficult, but you have to do it, you have to keep up, you have to try hard. We think... When you don't have it and you see it looks like it's worse than when you have it and you see other people talking about it. It seems that it's more associated to me, more relevant. I understand better now (e41, 19 years old, ovary).

In the lower left quadrant, the elements of the contrast zone are allocated which have a low frequency (less than 16) and an invocation order below the mean (2.70). The triad found from the elements scary-denial-sadness composes negative representation dimensions and reflects the social and psychological adaptation of patients to their diagnosis. This quadrant has the articulating meaning of denial, an attitude which permeates escaping from negative thoughts, the feeling of sadness and fear caused by the diagnosis, as the patients revealed:

But I don't think about the disease, but I don't hide it either: if the person asks I say it, I don't hide. I'm not going to be depressed because of this, I won't be locked inside a room, locked inside the house, under the covers, I'm not! (e40, 42 years, rectum).

I don't have to show sadness or anything. You have to deal with $i$, so what's the use of me crying, whining, then... (e13, 54 years old, head and neck).

Look, the cancer does not scare me at all, I don't let it bother me. We know it's a serious disease, a treacherous disease, let's say. But I don't worry, I don't worry at all. It is in the hands of God and the doctors. I don't worry at all, when I knew, I didn't let it shake me (e84, 66 years old, breast).

In observing the Cartesian plane which gives rise to the Vergès matrix, there is the first and second peripheries of the representation to the right of the ordinate, located in the upper and lower right quadrants respectively, composing the peripheral system. These elements are more flexible, they exert a function of defending the representation against changes, closely related to the $\mathrm{CN}$, because they hold the different positions present in the representation. The terms of the first periphery have a high frequency $(\geq 16)$ and mean evocation order equal to or greater than 2.70, which in this study is formed by the words God, treatment and cure. The term God was the most frequent and readily evoked in this quadrant, followed by treatment and cure, all interrelated by the patients. From the discourses, it is possible to demonstrate that curing can only be achieved with treatment or by the help of God, if not by the two forces in union to reach the ultimate goal: the absence of disease.

I believe, God left the doctors for this, otherwise he wouldn't have left the doctors to do the treatment. Now because I feel cured, I won't do the treatment? So you have to continue, everything has steps, they have to be followed, I don't give up treatment (e23, 47 years old, breast).

(...) that's what makes me do it ... Knowing that I'm going to be cured. That I've said that anything can kill me, but the cancer won't, because I trust in the God that I serve. So, I think like this, if our thinking and what comes out of our mouths have strength, then I am cured. So that's what I believe in, and it's just a phase, it's going to pass. (e25, 52 years old, breast).

Today we see that it is not the end of the world, that there are a lot of people who get cured, a lot who did the treatment and today they are okay, everything is calm, so today I see it like this (e85, 51 years old, breast).

The second periphery is composed of elements closer to daily life and also protects the representational formation. They are the less frequent and not readily evoked elements, 
with frequencies below 16 in this study, being: family, fight, hope and pain.

Family, fight and hope are related as positive strategies used by patients in order to protect themselves against the damage that illness can cause them. The family is highlighted as the element with the greatest number of evocations in the $2^{\text {nd }}$ periphery, considering its role as a source of support and care for the cancer patient, in the context of coping with the disease:

But every day in the morning I go to see my family, then I go home, they live on an acreage. So just seeing them is already okay. Right now my brother called me, a little while ago, so that's okay (e1, 54 years old, oropharyngeal).

(...) the whole family changes. Change, everyone changes. They start to notice us more, to give more affection to us, an excess of affection. And we also with them, we begin to have more patience (e85, 51 years old, breast).

In this scenario, the fight is the attitudinal element of the second periphery, which represents a positive way of behaving in dealing with the fact of cancer, establishing an active position in relation to the disease, as the patients report:

So if you do the treatment, you have to fight, and get over it. There are so many people who get over it, so we have to fight. A lot of people do, right here, even today talking to a girl, she's been doing chemo for 11 years, and she's got a 2-year-old little boy, so it's encouraging. It's when we are doing the treatment we get very ... But you have to fight, do treatment, then you have to fight until the last minute of life (e67, 45 years old, thyroid).

Because the diagnosis ... We don't wait, but we have to fight. But then we see that there are people worse than us, going through worse problems than us (e98, 26 years old, lymphoma).

Hope belonging to the affective dimension of representational construction was the term most readily evoked in the second periphery, and is reflected in confidence and optimism during cancer treatment which enables the patient to glimpse their cure.

Hope, lots of hope. We know that science is advanced, and that there are many cases of being cured with a healthy life extension. Because in about 4, 5 years she can come back again and this treatment will not work, there are many people that this happens to (e66, 53 years old, breast).

(...) I'm a flawed human too, so it wouldn't be normal for me to tell you that it's okay, it wouldn't be. But we have to fight. But that's it, while there is life, there is hope (e25, 52 years old, breast).

The term pain is the only one that presents as totally negative to the right of the Cartesian plane, being revealed as a consequence associated with cancer, capable of substantially impacting the daily life of the patient:

(...) changed is that I have to leave the service, I can't do anything, I can't work, I'm in pain... (e15, 34 years old, esophagus).

You see, I do almost nothing because of the discomfort, but then with pain you also do nothing, because then you are desperate, the pain drives you crazy. I'm afraid to be sulky, it's better to be quiet than to be... That's the biggest problem, being like this. (e25, 52 years old, breast).

The interpretative analysis of the Vergès matrix in association with the patients' speeches promotes the discussion of this study, in addition to the bases already built on this knowledge.

\section{DISCUSSION}

The study of cancer as an object of social representation has a theoretical basis and incontestable results for each moment and realities already studied ${ }^{(3,7,14)}$. However, new images, concepts or attitudes can be associated with a representation in order to integrate different conformations that affect the object from the studied social group. Each representational element is important during the healthcare of the human being, considering the complexity that is installed in the daily life of a sick person in both the individual and in the social context.

In this study, the presence of the term normal disease in the $\mathrm{CN}$ of the social representation adds a positive or neutral element to the evaluative construction on cancer, which until then had been negative in studies carried out on the subject ${ }^{(3,7,14)}$. The apparent ambivalence portrayed in the $\mathrm{CN}$ of this representation which contrasts the continuity of life by the element of normal disease, and its finality from the term death, brings forth an inferential hypothesis that relates normal disease to treatment and cure; elements which are present on the $1^{\text {st }}$ periphery.

From this reflection, it is possible to affirm that the reference to normal disease is related to the possibility of treatment, control and cure of cancer. The term normal disease can be considered as a recent social construction, meaning that it is possibly a new evaluation of cancer which is associated with positive results from therapeutic processes aimed at curing the disease.

In fact, the incurability of cancer is not as significant as it used to be: there has been important advances in the diagnosis and treatment of various types of neoplasia, progressively increasing the survival of these patients ${ }^{(15)}$.

From this analysis, the terms fear and death, also present in the $\mathrm{CN}$ of this representation, can express cancer-related conditions that have been constructed throughout the history of the disease. In view of this, it is possible to support the hypothesis that these elements are present in the collective memory related to the neoplasia mainly observed in the past, and which still intimidate patients living with cancer.

This inference is supported by a study of the memory status in the structure of social representations, from which the author assures that one of the characteristics of the $\mathrm{CN}$ would be to mark the collective memory of a group, reflecting its socio-historical values and conditions ${ }^{(16)}$, which possibly occurs in the presented structure. It is worth remembering that the terms fear and death have already been associated with the representations of cancer in other studies, which reaffirms its permanence as content participating in the representation of cancer $^{(3,7)}$. 
Corroborating this inference, a study of the social representations of cancer states that disease-related stigma have undergone several changes throughout history: neoplasms, which were previously fatal, can now be shaped as a chronic pathology, even though their epidemiological characteristics and therapeutic factors favor negative social representations about it. Despite a subtle disconnect of stigma attached to death, cancer still poses a threat to patients and has the power to affect the well-being of sick people ${ }^{(17)}$.

Thus, with regard to fear, its association is considered with anguish and threat related to cancer illness, as well as to the challenge of the disease, its attack on life and the unexpected, including mentioning the fact that one does not want to hear the word cancer or even know its meaning ${ }^{(3)}$. Fear of cancer is a present feeling in society, to a greater degree among people already diagnosed with the disease, but also prevalent in the general population ${ }^{(18)}$.

In addition, cancer is related to something that is difficult, since it has a symbolic burden related to suffering, which is associated with the difficulty of controlling the disease and surviving after diagnosis ${ }^{(2)}$. In addition, the antineoplastic treatment is complex and imbricated in peculiarities, which leads to new difficulties demanding persistence in the search for the daily well-being ${ }^{(19)}$. In this sense, it is possible to infer from the $\mathrm{CN}$ of the representation that cancer, despite being considered a normal disease by patients, still carries within itself the fear of death and has a difficult treatment to go through.

The elements present in the zone of contrast - scary, denial and sadness - reaffirm fear, present in the $\mathrm{CN}$ by means of the evaluative term scary, in addition to complementing the terms difficult and death through the functional element of sadness. The contrast zone did not show a disparity in terms of new meanings in comparison to the other quadrants, reserving its function of reinforcing the other present dimensions, especially in the central nucleus.

In this sense, the triad found in the contrast zone from the elements scary-denial-sadness composes negative representation dimensions and reflects the patients' resistance to their diagnosis. This quadrant has denial as an articulating element, constituting a term of attitudinal nature that expresses the desire to not think or talk about the disease and an escape from feelings which cause suffering to the patients. It can be inferred that during cancer illness, the severity of the disease is denied as a way to cope with it, the fear of death, pain and sadness, in an attempt to reinforce the conception of cancer as a normal disease. Thus, the term normal disease can be reinforced by denial, meaning that the patient reaffirms the cancer as a normal disease in their living in order to deny the sufferings associated with the experience of the disease.

Following this reasoning, the literature reveals that there is a relationship between stigma and social behavior ${ }^{(20)}$. In the case of cancer, stigmas have been created on the disease from several preconceived ideas, which may explain coping behaviors by patients, such as the use of euphemisms to designate the disease which help to re-signify cancer, and feelings of pity or fear associated with it socially ${ }^{(20)}$.
Regarding the peripheral system, the analysis of the presented elements reiterates the system's applicability, which has the functions of concretization, regulation and defense ${ }^{(10)}$. The concretization results from anchoring each representation to the concrete reality in order to make it understandable and transmissible. The regulation integrates new information or changes in the environment, since the peripheral elements are mobile and evolutionary within the representations. The defense function has the purpose of dealing with contradictions, which are tolerated by the peripheral system from its transformation in order to protect the $\mathrm{CN}^{(10)}$.

In the first periphery, the presence of the triad cure, God and treatment stands out. This quadrant focuses on attaining the cure for cancer from two non-opposing facets: scientific knowledge of treatment and belief in a higher entity, expressed by faith and religiosity $(G o d)$. In this sense, the term cure centralizes the understanding of the first periphery, meaning that the cure can have its functional character supported both in the belief in a higher entity (God) by restoring health by non-tangible means, as well as by performing treatment based on therapeutic and technological precepts. In this sense, the cure for cancer can be achieved as a consequence of the treatment and/or God's action in the fight against disease and death.

The presence of God and of spirituality has already been revealed in other studies on the subject ${ }^{(3)}$, in which the authors affirm that the thought and evocation of a higher entity have value for sick patients, helping them to even understand the diagnosis based on explanations about the moment they experienced. Thus, patients can cling to miracles or be entrusted with a mission of life, with spiritual or divine purpose ${ }^{(3)}$. These strategies help cope with the disease and give encouragement and hope to patients who are ill, as well as giving strength to the fight against cancer.

It is further verified that the double belief in a cure achieved by divine work and clinical treatment is reinforced by hope, an element present in the second periphery, which is based on both medical knowledge and faith in God. In this sense, hope, although often based on non-tangible means, constitutes an important strategy in coping with cancer. Hope is not only based on a cure, but also on the perspective of temporality in the sense of having a "bealthy life extension", as seen in the speeches. It is therefore the task of the health team to assist the patient to maintain high levels of hope during the course of the cancer, while providing support for assertive information about the disease and prognosis, helping them to deal with the uncertainties of the therapeutic path ${ }^{(21)}$.

The second periphery introduces the term fight, an attitudinal element that represents a positive way of behaving to face the facticity of cancer, establishing an active position in relation to the disease. Fighting is able to organize the subjects' daily lives during treatment, motivated by the hope to be cured. In addition, the social environment expects the sick person to position themself in front of the resources they have to face cancer, which can be reinforced when the human being starts to fight against the disease ${ }^{(3)}$. Thus, fighting is 
associated with hope, in the sense that it constitutes an attitude motivated by the desire to be cured, meaning that the fight is born out of hope to be cured.

In this scenario, the support and focus of thinking in the family and in the children are important elements for the representational construction of these patients. This condition reveals positive evaluations of the family in the context of cancer in the sense of being present in the evocations before the social attribution that it possesses, especially regarding protecting a loved one with the disease. In addition, the family is also a source of inspiration for life, so that patients seek to live by the thought of the other.

The family is part of the entire therapeutic context associated with cancer, which has repercussions on changes in the dynamics and interpersonal and social relationships among its members. Family life gains a new context based on changes in lifestyle and preferences in order to adapt choices, prioritize the life of family members, as well as act in an attempt to understand others more and enjoy time with loved ones ${ }^{(22)}$.

It is also important to emphasize that the presence of the term pain in the representational periphery indicates that it is possibly a physical and psychological symptom expected from the diagnosis of cancer. Pain is of concern to those who undergo antineoplastic treatment and to the survivors of the disease $^{(23)}$. In addition, experiencing painful perception may involve both physical dysfunctions, beliefs, coping strategies, and social interactions of the patient ${ }^{(24)}$. In this sense, the pain sensation shows itself as a significant obstacle in the daily lives of these people, making it impossible to continue the routine or to perform simple everyday tasks.

The representational construction presented herein is constituted by elements that permeate the daily lives of cancer patients in a way which enables delineating living with this disease. The contents observed in the representational structure allow to affirm it as a social representation, considering the presence of the elements which establish its construction by the social subjects, namely: the attitude, the information and the field of representation or image ${ }^{(11)}$. The meanings present in the prototypical analysis are confirmed through the patients' speeches in order to contribute to understanding cancer from the perspective of those who experience it, encouraging an increase in the healthcare of these people.

A limitation of this study would be that the data collection only occurred with people undergoing chemotherapy and in a single institution with specific economic, cultural and social characteristics, which does not allow comparisons or generalizations. In addition, the use of structural analysis and in-depth interviews may have left gaps or biases in interpreting the object being studied. Thus, it is considered that the use of new forms of analysis for the object could confirm (or not) the configuration found herein, being important for the construction of its social representations.

\section{CONCLUSION}

Contents and dimensions which compose the social representation of cancer by chemotherapy patients with respect to knowledge, images, attitudes, feelings and memory were identified in this study.

Such structural dynamics evidenced an organization of the social representation of cancer affected by the disease memory in contrast to its current configuration, which until now had not been evidenced in the literature, as well as the presence of a positive or neutral element in the central nucleus of the representation. This is organized through the memory of cancer being associated with fear and death, while at the same time the severity of therapy is evaluated as difficult. This scenario diverges from the configuration of cancer as a normal disease, based on its high prevalence and the possibility of treatment and of being cured.

Research on the social representations of cancer based on the presented interrelationships can contribute to understanding the disease from the perspective of the patients who experience it, providing reflections which enable professional development in cancer care.

In this sense, this study may become a support tool in providing care for people undergoing antineoplastic treatment, especially in relation to an increase in individual care, to deconstruct the denial and fear of the disease, manage pain and sadness, and to aid in the difficulties imposed by cancer. In addition, social and informative support to patients with malignant neoplasm and their family can contribute to coping with the disease, maintaining hope and treatment continuity so that the cancer is actually conceived as a normal disease.

It is believed that studies on the social representations of cancer with people in other treatment stages or people who do not have the diagnosis could foster an understanding of the implications of antineoplastic treatment in the representational construction on the disease.

It is therefore suggested that new studies be carried out in order to confirm the presence of positive elements in the central nucleus of the cancer representation in order to reiterate the evidenced structure.

\section{RESUMO}

Objetivo: Descrever os conteúdos e a estrutura da representação social do câncer. Método: Estudo qualitativo, embasado na Teoria das Representações Sociais, realizado em uma Unidade de Assistência de Alta Complexidade em Oncologia. Para a coleta de dados, empregaram-se questionário de caracterização sócio-ocupacional e clínica e formulário de evocações livres em 100 pacientes com câncer em tratamento quimioterápico e entrevistas em profundidade com 29 deles. A análise foi realizada com auxílio do software EVOC. Resultados: Participaram do estudo 100 pacientes. A representação social do câncer possui em seu núcleo central as palavras doença normal, difícil, morte e medo. A aparente ambivalência entre a continuidade da vida e sua finitude como significados estruturadores dessa representação permite estabelecer uma hipótese inferencial que relaciona a doença normal à possibilidade de tratamento, controle e cura do câncer, enquanto o medo da morte permanece no campo representacional atrelado à doença, que possui um tratamento difícil de ser enfrentado. Conclusão: As representações sociais do câncer, a partir das inter-relações apresentadas, propiciam reflexões que podem contribuir para o incremento do cuidado individual e social do paciente com neoplasia maligna e sua família, nos serviços de saúde.

\section{DESCRITORES}

Neoplasias; Enfermagem Oncológica; Psicologia social. 


\section{RESUMEN}

Objetivo: Describir los contenidos y la estructura de la representación social del cáncer. Método: Estudio cualitativo, fundado en la Teoría de las Representaciones Sociales, llevado a cabo en una Unidad de Asistencia de Alta Complejidad en Oncología. Para la recolección de los datos, se emplearon cuestionario de caracterización socio-ocupacional y clínica y formulario con libre evocación de palabras en 100 pacientes con cáncer en tratamiento quimioterápico y entrevistas en profundidad con 29 de ellos. Se realizó el análisis con la ayuda del software EVOC. Resultados: Participaron en el estudio 100 pacientes. La representación social del cáncer tiene en su núcleo central las palabras enfermedad normal, difícil, muerte y miedo. La aparente ambivalencia entre la continuidad de la vida y su finitud como significados estructuradores de dicha representación permite establecer una hipótesis inferencial que relaciona la enfermedad normal con la posibilidad de tratamiento, control y curación del cáncer, mientras que el miedo a la muerte permanece en el campo representativo vinculado a la enfermedad, que tiene un tratamiento difícil de enfrentarse. Conclusión: Las representaciones sociales del cáncer, mediante las interrelaciones presentadas, proporcionan reflexiones que pueden contribuir al incremento del cuidado individual y social del paciente con neoplasia maligna y su familia, en los servicios sanitarios.

\section{DESCRIPTORES}

Neoplasias; Enfermería Oncológica; Psicología Social.

\section{REFERENCES}

1. Herr GE, Kolankiewicz ACB, Berlezi EM, Gomes JS, Magnago TSBS, Rosanelli CP, et al. Avaliação de conhecimentos acerca da doença oncológica e práticas de cuidado com a saúde. Rev Bras Cancerol. 2013;59(1):33-41.

2. Lerner K, Vaz P. "Minha história de superação": sofrimento, testemunho e práticas terapêuticas em narrativas de câncer. Interface (Botucatu). 2017;21(61):153-63.

3. Palacios-Espinosa X, Zani B. Representaciones sociales del cáncer y de la quimioterapiaen pacientes oncológicos. Diversitas Perspect Psicol. 2014;10(2):207-23.

4. Ferreira DM, Castro-Arantes JM. Câncer e corpo: uma leitura a partir da psicanálise. Analytica. 2014;3(5):37-71.

5. Sette CP, GradvohI SMO. Vivências emocionais de pacientes oncológicos submetidos à quimioterapia. Rev Psicol UNESP. 2014;13(2):26-31.

6. Alcantara LS, Sant'Anna JL, Souza MGN. Adoecimento e finitude: considerações sobre a abordagem interdisciplinar no Centro de Tratamento Intensivo oncológico. Ciênc Saúde Coletiva. 2013;18(9):2507-14.

7. Leitão BFB, Duarte IV, Bettega PB. Pacientes com câncer de cavidade bucal submetidos à cirurgia: representações sociais acerca do adoecimento e tratamento. Rev SBPH. 2013;16(1):113-40.

8. DeSantis CA, Lin CC, Mariotto AB, Siegel RL, Stein KD, Kramer JL, et al. Cancer treatment and survivorship statistics, 2016. CA Cancer J Clin. 2016;66(4):271-89.

9. Charles C, Dauchy S, Bungener C. Choix thérapeutiques: s'appuyer davantage sur les representations individuelles des traitements. Bull Cancer. 2013;100(10):999-1005.

10. Abric JC. A abordagem estrutural das representações sociais: desenvolvimentos recentes. In: Campos PHF, Loureiro S, organizadores. Representações sociais e práticas educativas. Goiânia: UCG; 2003. p. 37-57.

11. Moscovici, S. Representações sociais: investigações em psicologia social. Petrópolis: Vozes; 2013.

12. Sá CP. Estudos de psicologia social: história, comportamento, representações e memória. Rio de Janeiro: Ed UERJ; 2015. Teoria e pesquisa do núcleo central das representações sociais; p. 209-26.

13. Oliveira DC, Marques SC, Tosoli AM. Análise das evocações livres: uma técnica de análise estrutural das representações sociais. In: Paredes AS. perspectivas teórico-metodológicas em representações sociais. João Pessoa: Ed. UFPB, 2005. p. 573-603.

14. Rodríguez AMC, Palácios-Espinosa X. Representaciones sociales del câncer y de la quimioterapia. Psicooncología. 2013;10(1):79-93.

15. Nascimento FB, Pitta MGR, Rêgo MJBM. Análise dos principais métodos de diagnóstico de câncer de mama como propulsores no processo inovativo. Arq Med. 2015;29(6):153-9.

16. Sá CP. O núcleo central das representações sociais. Petrópolis: Vozes; 1996. A teoria do núcleo central das representações sociais; p. 51-98.

17. Knapp, S. Marzilian A, Moyer A. Identity threat and stigma in cancer patients. Health Psychol Open. 2014;1(1):2055102914552281

18. Nelissen S, Beullens K, Lemal M, Van den Bulck J. Fear of cancer is associated with cancer information seeking, scanning and avoiding: a cross-sectional study among cancer diagnosed and non-diagnosed individuals. Health Info Libr J. 2015;32(2):107-19.

19. Milagres MAS, Mafra SCT, Silva EP. Repercussões do câncer sobre o cotidiano da mulher no núcleo familiar. Ciênc Cuid Saúde. 2016;15(4):738-45.

20. Palacios-Espinosa X, Zani B. La stigmatisation de la maladie physique: le cas du cancer. Psycho Oncol. 2012;6:189-200.

21. Borneman T, Irish T, Sidhu R, Koczywas M, Cristea M. Death awareness, feelings of uncertainty, and hope in advanced lung cancer patients: can they coexist? Int J Palliat Nurs. 2014;20(6):271-7.

22. Assis CL, Alves GF. Vivências e estratégias de enfrentamento em uma família com doente crônico com câncer. Rev Psicol Saúde. 2015;7(2):142-51.

23. Goodwin PJ, Bruera E, Stockler M. Pain in patients with cancer. J Clin Oncol. 2014;32(16):1637-9.

24. Reticena KO, Beuter M, Sales CA. Life experiences of elderly with cancer pain: the existential comprehensive approach. Rev Esc Enferm USP. 2015;19(3):417-23. DOI: http://dx.doi.org/10.1590/S0080-623420150000300009 